\title{
DIGGING FOR DODO
}

\section{ドードーの実像に迫る}

Nature Vol. 443.(138-140)/14 September 2006

ドードーが姿を消して 350 年がたつというのに、この絶滅鳥類に関する突飛な推理は消えることなく続いている。モー リシャス島で近年行われている発掘作業で、この生き物の実像が明らかになるだろうか。Henry Nichollsが取材報告する。

ドードーはおそらく絶滅の象徵として 最も有名な動物だが、絶滅に至った正 確な時期や経緯については誰も知らな い。実際、この飛べない鳥について多 くのことを知る者は、現在のところ皆 無である。16 世紀初頭、ポルトガル やオランダの水夫たちが初めて目撃情 報を伝えた時期の直後まで、ドードー はインド洋のモーリシャス島に生息し ていた。世間に広がったイメージか ら、ドードー（モーリシャスドードー、 Raphus cucullatus）はずんぐりとした鳥 (ハトの仲間) で、巨大なくちばしをも ち、鼻孔が大きく目はギョロリとして いたという見方が定着している。
しかし不格好なこの姿は、人づてに聞 いた話や保存状態の悪い剥製標本から生 み出されたまったく架空のドードー像な のかもしれない(コラム「架空のドードー 像」参照)。ドードーの骨は数千個あり、 ドードーの研究も数百件あり、ドードー を大好きな人々は数えきれないほどい るが、ドードーが実際にどのように暮ら して死んでいったかを解明する助けには なっていない。「我々は事実上、まだドー ドーについてまったく何も知らないので す」と、ロンドン自然史博物館の鳥類古 生物学者である Julian Hume はいう。

しかし、こうした状況も、モーリシャ ス島の Mare auxSonges (地図参照)
とよばれる沼地で行われている新しい 発掘調査のおかげで、まもなく変わり そうだ。オランダの地質学者 Kenneth Rijsdijk が率いる調査チームは、ドー ドーの骨の発掘に最も重要と思われる 遺跡をすでに 2 年連続で訪れている。 この場所は数十年間にわたって手つか ずの荒れた状態だったが、今後数年で この遺跡の泥から、これまで発見され ているドードーの骨の数を 1 桁上回る ほど大量の骨が見つかる可能性がある。 また、この遺跡には細菌からゾウガメに 至る完全な生態系が封じ込まれており、 ドードーの遺骸化石といっしょに保存さ れている。総合すると、この発掘調査に 
よって、謎に包まれたこの鳥の生と死を 知るための貴重な手がかりが、まず確実 につかめるだろう。そしておそらく、滅 んで久しいドードーの忠実な復元像も初 めて見せてくれることだろう。

意外に思えるかもしれないが、学者た ちの意見は、ドードーを実際に絶滅に追 いやった原因を含め、非常に多くの基本 的事実に関して一致していない。現在、 次のようなさまざまな可能性があげられ ている。島にやってきた水夫たちがドー ドーを大量に捕まえて食べたために、 ドードーの個体群を崩壊させてしまった のかもしれない。あるいはひょっとする と、水夫たちがドードーの生息地を取 り返しがつかないほど破壊してしまった か、島の生態系を壊すような哺乳類（特 にネズミやブタ、ヤギ）を持ち込んだの かもしれない。または、熱帯低気圧など による自然災害がドードーをほとんど絶 滅に近い状態まで追い込み、その後に水 夫たちが上陸したのかもしれない。専門 家が推すのはネズミ持ち込み説だが、こ の時代までタイムトラベルでもしない限 り確認するのは不可能である。

ドードーが最終的に姿を消した年につ いても、見解は分かれている 1 .Hume は Nature 誌上で、モーリシャスの首長の 1 人による詳しい狩猟記録から、彼の家 来たちが 1685～1688 年の間に少なく とも 1 ダースのドードーを仕留めたこと がある、と主張した2。これに異議を唱 える者もおり、その 1 人はHume の友 人であり同僚でもあって、英国鳥学会に よる 1970 年代のモーリシャス調査旅行 の隊長も務めた Anthony Cheke である。 Chekeによれば、首長の狩猟記録にある 「dodaersen」という言葉は、モーリシャ ス島にいた別の飛べない鳥であるモーリ シャスクイナ (Aphanapteryx bonasia) を 指す表現として、1660 年代まで使われ た言葉だという ${ }^{3,4}$ 。Cheke の主張によ ると、信頼できるドードーの最後の目撃 情報は、1662 年に難破した水夫の一団 がモーリシャス島から水の中を歩いて小 島まで行き、「ガチョウより大きい」数羽 の鳥を追い詰めたものだという。

\section{標本焼失}

姿を消した時期や経緯がどうであれ、ドー ドーに関する物があまり残っていないこと は事実である。水夫たちが国に持ち帰った のは、話やスケッチ、剥製にした鳥だった。 生きたままヨーロッパに持ち帰られたこと がわかっているのは、1 羽だけである。英 国オックスフォードにあるアシュモリアン 博物館に収蔵された骨格標本は、この持ち 帰られた唯一のドードーだったのかもしれ ない。しかし残念なことに、この貴重な標 本の頭部と脚 1 本を除くすべての部分は 1755 年に焼失してしまった。この話には、 1 人の勇敢な学芸員がかかわっている。彼 は炎の中に飛び込んで、標本の一部を切り 取り、完全焼失から標本を救ったのである。 世間に広く流布している話によると、実は この火事は偶発的なものではなく、保存状 態の悪化した標本を破棄する目的で、故意 に火がつけられたものだという。このとき 救い出された体の部分は、1 世紀以上にわ たって、世界で最も重要なドードーの遺物 として扱われた。

やがて 1865 年、モーリシャス島の 東海岸では Mare aux Songes のそば を走る鉄道線路を敷くために、技師た ちが土地を切り開いていた。その地元 の学校教師だった George Clark は、 敷設用の掘削中に露出したドードーの 骨を偶然にも発見し、さらなる骨を見 つけようと、現地労働者たちを指揮し て近くの沼地を手探りで進ませた。

Clark は結局、ドードーの骨のある貴 重な場所を見つけ出し、それらの骨をロ ンドン自然史博物館に売り渡した。ドー ドーに関して現在わかっている解剖学情 報の大部分は、19 世紀末までに Mare aux Songes で見つかったClarkの手 による骨やその他の骨（合計 $200 〜$ 300 個の骨) である。しかし、Clarkの 下で作業した人々の技量が未熟で粗雑 だったために、Mareaux Songes から 1 羽分の完全骨格が出ることはなかっ た。世界各地の博物館で展示されてい るドードーの骨格標本のほとんどすべて は、Clarkやその後継者たちがこの沼地 から掘り出した数羽分の遺骸を継ぎは

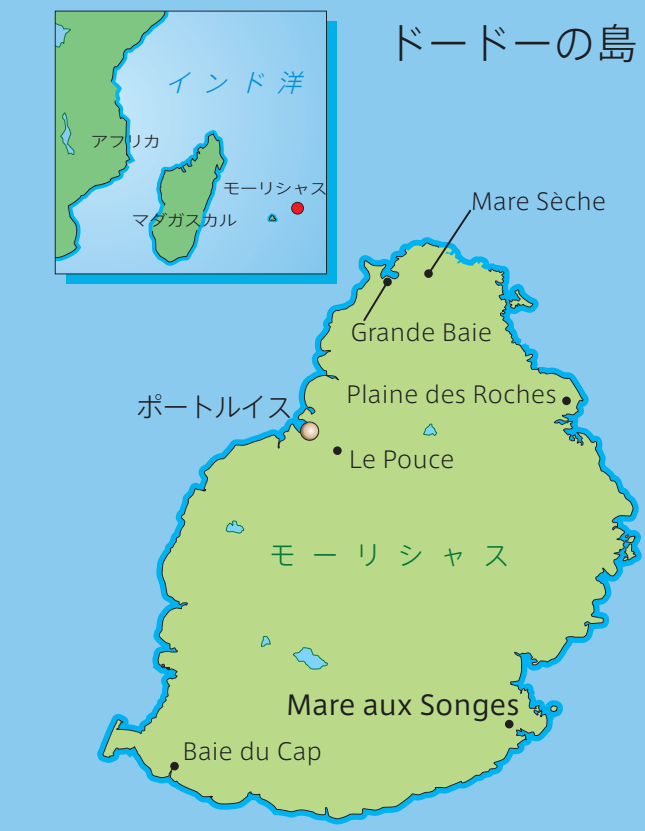

(黒点はドードーの骨が見つかった場所)

ぎして、1 羽のドードーの形に何とかま とめたものである。

ただし例外が 1 つる。それはモー リシャスの首都ポートルイスにある モーリシャス研究所が所蔵する標本で、 6 フィート(180 cm 余り)のガラスケー スの中に立っている。この標本は、理 容師でドードー好きの Louis Etienne Thiriouxが 1890 年代に見つけたもの で、唯一の関節のつながった骨格標本 である。これはおそらく、ポートルイ スの南に位置するLe Pouce の洞窟で 出土したものだろう、とHume はいう。 しかし、Thiriouxはどうやら正確な出 土場所を秘密のままにしていたようで、 その後、2，3 人がわざわざ彼の足取り をたどったが何も見つけられなかった。 この渓谷は現在、雑草が生い茂って人 が通れない状態になっている。

\section{乏しい遺物}

モーリシャス島内の別の場所で、ドードー の遺物を探し続けた人々もいる。1974 年に、Mare Sèche のボーリング孔から 一握りのドードーの骨が見つかったが、 そこの土地所有者は古生物学者たちが発 掘するのを許可してくれなかった。「ほか の場所でも骨は見つけられるが、数が非 常に限られている」と、鳥類学者でモ一 

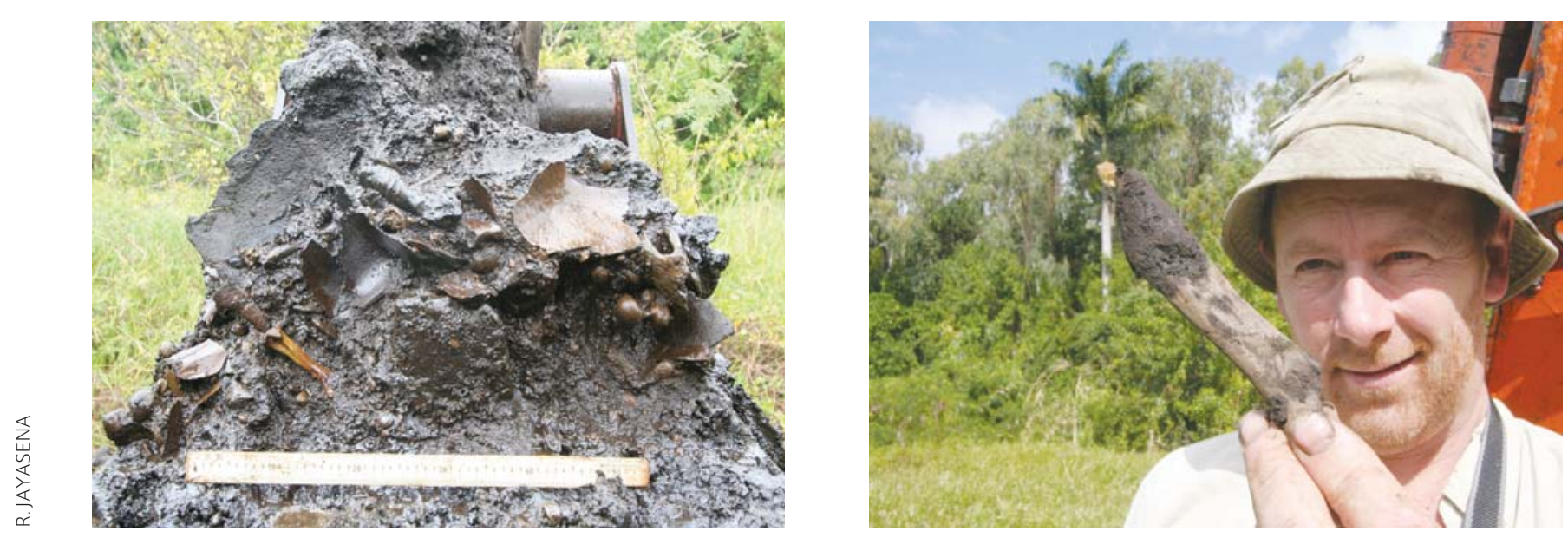

解明の鍵となるか? Julian Hume(右)が持ち上げているのは、モーリシャス島の沼地で得られた土壌試料(左)から見つかった多数のドードーの骨のうちの 1 つ。

リシャス国立文化財基金の顧問でもある AnwarJanoo はいう。例えば、Janoo は島の南端にある Baie du Cap の崖に 開口した洞窟で、いくつかのドードーの 骨破片を見つけている。彼の話による と、脱走した奴隷や囚人がこれらの洞窟 を隠れ家として使ったことがあり、見つ かった骨はおそらく脱走者たちが捕ま えて食べたドードーのものだろうとい う。Janoo はまた、北にある Plaine des Roches の崩れた溶岩トンネルの底で、 骨をいくつか見つけている 5 。

Janoo は、北部にあるもう 1 つのドー ドー遺跡を知っていると公言している。 そこは、フランス人古生物学者で映画製 作者でもある Didier Dutheil が 1999 年にドードーの頭骨後部を掘り出した 場所である。だが、Janooも Dutheil も正確なありかを口外していない。そ の秘密主義にはイライラさせられると、 Cheke はいう。「彼らがその場所に戻ら ず、もしくは少なくともその場所をだれ にも教えていないということには感心す るばかりだ」。

Mare aux Songes で見つかった 200 〜 300 個の骨、Thiriouxの見つけた 骨格、Janoo の骨の破片を合わせても、 今後の研究のためには明らかに数が少 ない。しかし、Mare aux Songes で最 近、発掘調査が行われるようになった のは、標本をさらに増やす必要性に迫ら れたからではない。ユトレヒトにあるオ
ランダ応用地球科学研究所に本拠地を 置くRijsdijk と彼の同僚である Frans Bunnikが 2005 年 10 月にその場所に 赴いたのは、むしろ偶然が積み重なった おかげである。彼らはドードーを探して いたわけではなく、1638 年にモーリシャ ス島にオランダ人が定住する以前の同島 の植生や気候を再現するのに役立ちそう な花粉サンプルを探していたのだった。

Rijsdijk と Bunnik は興味深い地点を いくつか特定したが、それらの場所の 1 つが当時より 140 年前にClark が発掘 した沼地であることに、2人とも気づい ていなかった。そこは海からそう遠く なく、サトウキビ畑に囲まれたジメジメ とした低地だった。1940 年代のこと、 当時の英国当局は、この島の蚊とマラ リアの蔓延に対処するため、Mare aux Songes を火山角れきで埋めるよう命令 を出した。Rijsdijk と Bunnik は、現地 の地主に教えられて、自分たちのいる場 所がどんなところか気づいた。その話に よると、日本からやってきたドードー好 きの人物の依頼で、1992 年にこの沼地 に5つのボーリング孔が掘られたのだ という。その作業を依頼した人物は掘り 出した掘削コアをまったく要求しなかっ たので、このオランダ人科学者 2 人が コアを見た最初の人間となった。

彼らは掘削コアの内容の豊かさに呆 然とした。「コアにはさまざまな種類 の堆積物が交互に詰まっていて、自分
たちの扱おうとしている題材が本当に ダイナミックな環境に置かれていたこ とをまざまざと知らされたのです」と Rijsdijk は語る。しかし、小さいながら

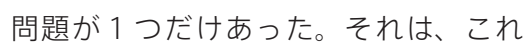
らのコアの本来あった場所を突き止め る必要のあることだ。ボーリング技師 の作成した大ざっぱな図には、海、1 本 の道、4本のヤシの木、そして 5 つのボー リング孔が描かれていたが、縮尺も方 位も記入されていなかった。「まるで宝 探しの地図だった」と彼は語る。

\section{ドードー探し}

彼らは見込みのある 1 か所の位置を決 めると、仮のコア掘削を始めた。「岩混 じりの石ころの層を 80 センチ突き進む のに 1 時間半もかかった」とRijsdijk はいう。だが、その下に彼らはドードー の骨を数十個見つけたのだった。

調査チームは 2006 年の 7 月、最も 期待できる区画を定位するためのレー ダーや、石だらけの最上層を取り除く ための掘削機、8メートルほどの深さ まで泥炭地を掘削するためのドリルを 携えて、発掘現場に戻ってきた。回収 された掘削コアには微生物や植物性物 質がびっちり詰まっており、トカゲや ゾウガメ、オウム、フクロウ、コウモ リの骨もいっしょだった。これらの堆 積物の年代は、放射性炭素を使った測 定年代でまもなく突き止められるだろ 
うが、得られたコアには外来種がまっ たく含まれていなかった。つまり、得 られたコアは、人間がモーリシャス島 に到来する前のドードーの世界を見せ てくれることになる。「これは、この(人 間到来前のドードーの）世界を再現す るまたとない機会を我々にもたらして くれるでしょう」とRijsdijk はいう。

実際のところ、Mare aux Songes の 遺跡によって把握できるのは、ドードー の一生のうちの一瞬だけではなく、もっ と多くの部分に及ぶのではないかと、 ニューヨーク州にあるフォーダム大学 の古生態学者 David Burney はいう。 「私は、得られるのは単なるスナップ ショットではないと予想している。動 画のように、多少連続的に過去に戻る 形で、景観の標本抽出ができるのでは ないか」と彼は述べている。Burney は
ハワイで研究しており、ポリネシア人 の到来によってハワイの生態系がどう 変化したかを調べている。同様に、モー リシャス島に関するこの調査から、自 然の力や人類の定住が島の生態系に及 ぼす影響が明らかになるかもしれない。

今夏の発掘調査は、小部屋ほどの大 きさの沼地エリアに集中した。そこか らは約 4000 個の骨が見つかり、その うち 200 ～ 300 個はドードーのもの だった。この調査の初期結果は、2006 年 9 月後半にロンドンで開催される 会議で発表されることになっている。 Mare auxSongesには、古生物学的 見地から出土が期待できる堆積盆地が 合計で3つある。これらはおよそ5へ クタールの範囲にわたり、ドードーの 骨を数万個含んでいる可能性があると、 Rijsdijk はいう。
このように豊かな発掘物が得られれ ば、科学者たちの知識の空白部分が一 部なりとも埋まるかもしれない。ドー ドーの雌雄は大きさが違っていたのだ ろうか? 雄は、大げさな形のくちば し、もしくは異性を引きつけるための 別の形質を誇示していたのだろうか?

$$
\text { ドードーの卵の大きさはどれくらい }
$$
か? そして、Mare aux Songes の これほど興味深い過去の遺物はどんな 形で結末に至るのか? それは自然災 害だったのだろうか？もしそうなら、 人間の到来以前にドードーはほぼ絶滅 状態に陥っていたとする説の信憑性が 高まることになるだろう。

一方、この沼地からはドードーの DNA も得られるのではないか、と期待 している人々もいる。こうした研究のも つ潜在的な可能性は、オックスフォー

\section{架空のドードー像}

ドードーを取り上げた読み物は 世の中に多数あるが、人づてに 聞いた話だったり話が矛盾して いたりするために、ドードーの 本当の姿についてさまざまな誤 解を招いてしまった ${ }^{7}$ 。

体色 目撃談はすべて、ドー ドーは灰色または黒っぽい色 だったとしているが、17世 紀にオランダでドードーに似 た白い鳥の絵が描かれ、これ らが混乱を招いてしまった。 これらの絵のうち一部は、す ぐ隣にあるレユニオン島から やってきて現在は絶滅してし まったトキの仲間 (Threskiornis solitarius) を描いたものである 可能性がある。他の絵は、ア ルビノのドードーを描いたも のである可能性があり、おそ らく体色が珍しいために特別 扱いされたのだろう。
体形 ずんぐりして足が短く不 格好な動物というドードーの一 般的イメージは、おそらくフラ マン人の画家 Roelandt Savery が 1626 年ごろに描いた 1 枚の 絵に由来するものだろうと、ドー ドー専門家の Julian Hume は いう。それより以前の絵では、 脚は長くて力強く、もっと直立 した姿勢をしている。しかし、 Savery の絵の複製はすぐに出 回ってしまった。1638 年以 降のドードーの絵は、どれも本 当の姿を描いたものとはいえな い」と Hume は話す。

鼻孔 多くの絵でドードーの 鼻孔は大きく開いて描かれて いる。これはおそらく、絵描 きたちのほぼ全員が死んだ剥 製標本をもとに絵を描いたせ いだろうとHume はいう。「皮 膚が乾くと鼻孔は開く」とい

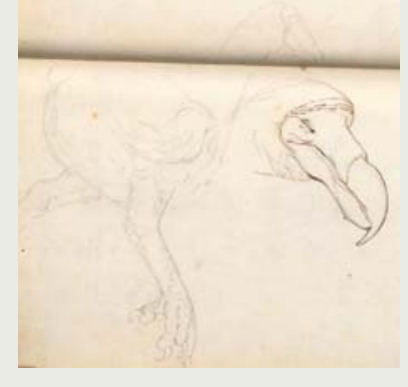

うのだ。生きている状態か死 んだばかりのドードーをもと に描いたことが明らかな、上 の 1601 年のスケッチに限る と、鼻孔はほとんど見えない。

食餌 ドードーが食べていた物 に関する情報はないに等しく、 推測ばかりがひとり歩きしてき た。1973 年に提唱されたある 説によれば、タンバラコクという 木の種子はドードーの消化管を 通り抜けないと発芽できず、ドー
ドーがいなくなってタンバラコク は減少の一途をたどっていると いう。しかし最近、モーリシャス 島でタンバラコクの若木が再発 見されて、この説は一蹴された。

食用に適するか ドードーは おそらく伝えられているほど にはまずくなかっただろうと、 Hume はいう。最古の説明書き の 1 つによれば、この鳥は「良 質の食用肉」となるが、水夫た ちが好んで食べたのはハト類や オウム類だったとしており、そ の理由はドードーが「忌まわし く不快な鳥」だったからだとい う。Humeは、この表現が誤解 されたのではないかと考えてい る。彼が思うに、ドードーは美 味だったが、こってりとして脂っ こかったので、水夫たちはすぐ にうんざりしまったのだろう。

H.N. 
ドのドードー標本の足から抽出された DNA を材料とする既存の遺伝学研究で よく示されている。このときの解析から、 ドードーに最も近縁な現生祖先種はミノ バト (Caloenas nicobarica) であること や、ドードーとミノバトが 3000 万年以 上前に分岐したことが示唆されたのだ 6 。 しかし、この年代值は、火山性のモーリ シャス島が海中から出現した年代よりも かなり古い。新たな研究調査は、両種の 分岐と島出現の関係性の解明に役立つか もしれず、新情報も得られるかもしれな いと、古代 DNA の専門家であるオック スフォード大学の Beth Shapiro はいう。 「長期の地質年代にわたるドードーの大 量標本から古代 DNA を採取することが できたなら、絶滅に近づくにつれて個体 群サイズがどう変化していったかを知る ことができるかもしれない」と彼は話す。
ただし、Mare aux Songes の暑い 気候と酸性の土壇条件はDNAの保存に はまったく向いていない。泥の初期解 析から、数種の植物の DNA 配列が得ら れたが、ドードーのものと思われるよ うな DNA はこれまでのところ皆無であ る。「我々はまだあきらめていません」 とShapiroは話す。

しかし、ドードーは DNA がなくても ショーの主役であり続けるだろう。最後 のドードーがモーリシャス島のやぶの中 をのんびり歩いていた時代からおよそ 350 年、この鳥に関する認識は変化し続 けている。「ドードーはある意味では死 んでいるが、ある意味では元気に生きて いるのです」とRijsdijk はいう。

ドードーのもつ集金力は、今なお 健在である。Rijsdijk は非営利のドー ド一研究基金を創設し、来年 Mare aux
Songesへの調査旅行に資金を供給し たいと考えている。彼は、今夏使ったよ うな破壊的な機械技術を使わずに、丁 寧な発掘調査をするつもりでいる。来年 以降になれば、箱にいっぱい詰まった研 究用ドードーの骨にお目にかかれるか もしれない。そしてもしかすると、この 鳥にまつわる多くの作り話を一掃でき るだけの材料がそろうかもしれない。

Henry Nicholls はロンドン在住のフリーランス ライター。

1. Roberts, D. L. \& Solow, A. R. Nature 426, 245 (2003).

2. Hume, J. P., Martill, D. M., \& Dewdney, C. Nature 429 , doi:10.1038/nature02688 (2004)

3. Cheke, A. S. in Studies of Mascarene Island Birds (ed. Diamond, A. W.) 5-89 (Cambridge Univ. Press, Cambridge, 1987).

4. Cheke, A. S. Ibis 148, 155-158 (2006)

5. Janoo, A. Ann. Paleontol. 91, 167-180 (2005)

6. Shapiro, B. et al. Science 295, 1683 (2002).

7. Hume, J. P. Hist. Biol. 18, 65-89 (2006).

\section{ドードーの名を世界中に広めた物語}

ドードーは、児童文学『不思 議の国のアリス』の登場人物 として描かれ有名になった。 著者は英国の作家ルイス・キャ ロル (1832-1898)。刊行は 1865 年で、その後、世界中で 翻訳されて多くの読者に愛さ れた。日本語へも 1908 年 (明 治 41 年) に、最初の翻訳が行 われている。

物語は、アリスという名前の 少女が白ウサギの縦穴に落ち て、人間の言葉をしゃべる動物 などが住む不思議の世界へ迷い 込むという内容。いろいろなユ ニークなキャラクターが登場す るが、ドードーもその 1 つで、 第 3 章の「コーカス・レースと 長いお話」に出てくる。ドードー は、アリスや動物たちが涙の池 でぬれてしまった体を乾かすた めに、コーカス・レースを提案 する。このレースは、円形のコー
スをどっちにどれだけ走っても よい競走で、服が乾いたところ で終了となり、全員優勝、み んな賞品がもらえるというもの だ。物語中で、ドードーは何か 的外れなことをいう「デブでグ ズな鳥」とういうイメージで描 かれており、著者のキャロル自 身がモデルといわれている。彼 はどもり気味で、しばしば本名 の姓ドジソンを「ドー、ドー、 ドジソン」と発音したという。 キャロルは英国のダーズベリ 生まれで、オックスフォード大 学卒業後、母校で数学と論理学 の講師をしていた。あるとき、 友人とともに学長の 3 人の娘た ちを連れて、ピクニックに出か けた。そこで当時 10 歳のアリ スにせがまれ、アリスを主人公 とした即興のおとぎ話を語って みせる。その話が『不思議の国 のアリス』のもとになった。
では、キャロルはどこでドー ドーを知ったのだろうか? 彼 の勤務先オックスフォード大学 のアシュモレアン博物館には当 時、ドードーの骨格標本と油絵 (Roelandt Savery 画) が展示 されていた。時おり、ここを訪 れていたことがきっかけとなり、 物語にドードーを登場させよう と思ったのかもしれない。I.K.
著作権等の理由により画像を掲載することができません。 